\title{
PURIFIED GLYCERIN IN BALANCED DIETS FOR CHICKEN BROILERS FROM 8 TO 21 DAYS OLD
}

\author{
GLICERINA PURIFICADA EM DIETAS BALANCEADAS PARA FRANGOS DE \\ CORTE DOS 8 AOS 21 DIAS DE IDADE
}

\section{Mônica Calixto da SILVA ${ }^{1}$; Roberta Gomes Marçal Vieira VAZ ${ }^{2}$; Kênia Ferreira RODRIGUES ${ }^{2}$; Luciano Fernandes SOUSA²; José Henrique STRINGHINI ${ }^{3}$; Flávia Luzia Rodrigues FONSECA²; Iberê Pereira PARENTE ${ }^{4}$; Carla Fonseca Alves CAMPOS ${ }^{5}$ ' Latóya de Sousa BEZERRA ${ }^{5}$; Mayara da Cruz RIBEIRO5; Jefferson Rodrigues da SILVA ${ }^{5}$}

1. Discente de Pós-Doutorado, Programa de Pós-graduação em Ciência Animal Tropical, Universidade Federal do Tocantins, UFT, Araguaína, TO, Brasil. monicalixto_@hotmail.com; 2. Profs. Drs., Departamento de Zootecnia da Escola de Medicina Veterinária e Zootecnia, UFT, Araguaína, TO, Brasil; 3. Prof. Dr., Departamento de Zootecnia da Universidade Federal de Goiás, UFG, Goiânia, GO, Brasil; 4. Prof. Dr., Instituto Federal do Maranhão, IFMA, Presidente Dutra, MA, Brasil; 5. Discentes de Doutorado, Programa de PósGraduação em Ciência Animal Tropical, UFT, Araguaína, TO, Brasil.

\begin{abstract}
This paper aimed to evaluate the metabolizability, performance and economic viability of purified glycerin inclusion in balanced diets fed to chicken broilers from 8 to 21 days old. Two experiments were conducted. In the first experiment, 100 broilers (14 days old) were distributed in a completely randomized design into two treatments, with five replications of 10 broilers. Treatments consisted of a control diet and a test diet, in which purified glycerin replaced $10 \%$ of the control diet. In the second experiment, 200 broilers ( 8 days old) were distributed in a completely randomized design into four treatments $(0,2,4$ and $6 \%$ of purified glycerin inclusion), with five replications of 10 broilers. The weight gain, feed intake, feed conversion, final weight, apparent metabolizable energy (AME), nitrogen-corrected apparent metabolizable energy ( $\mathrm{AME}_{\mathrm{n}}$ ), metabolizability coefficients of dry matter (DMMC), crude protein (CPMC) and gross energy (GEMC), and the cost of feed per $\mathrm{kg}$ of broiler produced were evaluated. The AME, $\mathrm{AME}_{\mathrm{n}}, \mathrm{DMMC}, \mathrm{CPMC}$ and GEMC from the purified glycerin were 3790 and $3560 \mathrm{kcal} / \mathrm{kg}$, and 83.72, 71.52 and $86.27 \%$, respectively. The glycerin levels did not affect $(\mathrm{p}>0.05)$ any of the performance characteristics (weight gain, feed intake, feed conversion and final weight). The lowest feeding cost and the highest gross margin were obtained for broilers fed with $6 \%$ purified glycerin. The inclusion of $6 \%$ purified glycerin in balanced diets for broilers from 8 to 21 days old was technically and economically feasible.
\end{abstract}

KEYWORDS: Biodiesel. Energetic feed. Feeding cost. Metabolizable energy. Productive performance.

\section{INTRODUCTION}

The high feeding costs for chicken broilers, mainly due to the increased demand for corn, have motivated the interest of nutritionists to search for alternative sources of energy that can partially replace energetic feed in the diet. Among them, it is possible to highlight the biodiesel coproducts, as processing oils and fats obtained by saponification of fatty acids with sodium hydroxide or potassium hydroxide to produce biodiesel and glycerin as a coproduct (JUNG; BATAL, 2011a, 2011b).

Studies that evaluated the energy content of glycerin, evidenced its efficiency as an energy source for poultry feeding because it has a high metabolizable energy content. Nevertheless, in literature, different metabolizable energy contents are reported because factors, such as glycerin inclusion levels in the diet, age of the broilers, lack of standardization in the production process, in addition to different sources (plant or animal) can cause variation and interfere in feed composition (DOZIER et al., 2008; 2011; HENZ et al., 2014a; LIMA et al., 2013).

The results of previous studies conducted with the use of glycerin in broiler diets demonstrated its potential as an effective energy source for poultry nutrition at various production stages (CERRATE et al., 2006; GUERRA et al., 2011; ROMANO et al., 2014).

Cerrate et al. (2006) developed two experiments using 0,5 and $10 \%$; and $0,2.5$ and $5.0 \%$ glycerin levels in broiler diets and concluded that glycerin can be used at 2.5 or $5.0 \%$ without decreasing broiler productive performance. 
Divergent results were found by Romano et al. (2014), testing various glycerin inclusion levels $(2.5,5.0,7.5$ and $10 \%)$. These authors found that broilers were able to properly metabolize glycerin at up to $7.5 \%$ inclusion in the diet. Undesirable metabolic alterations, such as increased blood glucose concentration, water intake and fecal moisture, may occur at levels of glycerin higher than $7.5 \%$ (GIANFELICI et al., 2011; GUERRA et al., 2011; ROMANO et al., 2014).

However, studies carried out with the use of glycerin in poultry feed in regions of high temperatures, such as the North region, are scarce in the literature, which evidences the relevance of new studies, to enable the use of this subproduct on a commercial scale. The introduction of any alternative feed in broilers diet depends on laboratory tests and biological assays to assess the nutritional value and the best nutrient inclusion level, without compromising the performance traits and to provide cost-effective feeding. In this context, this paper aimed to evaluate the metabolizability, performance and economic viability of purified glycerin inclusion in balanced diets for chicken broilers from 8 to 21 days old.

\section{MATERIAL AND METHODS}

Two experiments were conducted at the Poultry Sector of the School of Veterinary Medicine and Animal Science, Federal University of Tocantins, located in Araguaína, Tocantins, from January $31^{\text {st }}$ to February $14^{\text {th }}, 2014$. These experiments were approved by the Ethics in Animal Use Committee of the Federal University of Tocantins (CEUA-UFT) under the protocol number 23101.000830/2014-16.

In the first experiment, a metabolism trial was performed using 14-day-old male broilers from the Cobb $500^{\circledR}$ lineage, located in metabolic cages, with gutter feeders and drinkers. The broilers were acclimatized for 5 days and the two treatments then distributed in a completely randomized design (CRD) with ten replicates of four birds per experimental unit, totaling 100 broilers.

The two treatments consisted of a reference formulated diet used to meet the broilers nutritional requirements, according to Rostagno et al. (2011) (Table 1) and a test diet, in which, based on the organic matter, the purified glycerin replaced $10 \%$ of the reference diet. Thus, the test diet consisted of $90 \%$ of the reference diet and $10 \%$ of purified glycerin (the purified glycerin composition is provided in Table 2).

During the 5-days subsequent to acclimatization, the total excreta was collected and feed intake (FI) was also evaluated during this period. Samples were collected twice a day $(8 \mathrm{a} . \mathrm{m}$. and 4 p.m.), preventing fermentation and possible loss of nutrients from the excreta. After collection, the excreta were packed in plastic bags, properly identified and then frozen. At the end of the experiment, the excreta of each treatment was defrosted at room temperature and homogenized according to the method proposed by Sakomura and Rostagno (2007).

From each experimental unit, $400 \mathrm{~g}$ of excreta was pre-dried in a forced ventilation oven at $55^{\circ} \mathrm{C}$ for 72 hours, to determine the oven-dry sample weight. Next, experimental diets and excreta samples were sent to the laboratory of Tropical Animal Science, at the Federal University of Tocantins, to determine dry matter (DM), mineral content (MC), crude protein (CP) and gross energy (GE), which were determined according to the procedures described by Silva and Queiroz (2002).

Table 1. Centesimal and calculated reference diet composition (based on organic matter)

\begin{tabular}{lc}
\hline Ingredients & $(\%)$ \\
\hline Corn meal & 61.498 \\
Soybean meal (45\%) & 33.167 \\
Dicalcium phosphate & 1.783 \\
Soybean oil & 1.346 \\
Limestone & 0.826 \\
Salt & 0.436 \\
DL-Methionine & 0.248 \\
L-Lysine HCl & 0.234 \\
L-Threonine & 0.062 \\
Mineral and vitamin supplement ${ }^{1}$ & 0.400 \\
\hline Total & 100.00 \\
\hline Calculated nutritional composition & \\
\hline
\end{tabular}




\begin{tabular}{ll}
\hline ME (kcal/kg) & 3000 \\
Crude protein (\%) & 20.79 \\
Calcium (\%) & 0.884 \\
Available phosphorus (\%) & 0.442 \\
Digestible lysine (\%) & 1.146 \\
Methionine + digestible cystine (\%) & 0.814 \\
Digestible methionine (\%) & 0.536 \\
Digestible threonine (\%) & 0.745 \\
Ether extract (\%) & 3.918 \\
Sodium (\%) & 0.214 \\
Potassium (\%) & 0.795 \\
Chlorine (\%) & 0.294 \\
Electrolyte balance (meq/kg) & 213.5 \\
\hline
\end{tabular}

${ }^{1}$ Composition (ton ${ }^{-1}$ ): Folic Acid: $150.00 \mathrm{mg}$; Cobalt: $178.00 \mathrm{mg}$; Copper: $2675.00 \mathrm{mg}$; Choline: $120.00 \mathrm{~g}$; Colistin: 2,000.00 mg; Iron: $11.00 \mathrm{~g}$; Iodine: $535.00 \mathrm{mg}$; Manganese: $31.00 \mathrm{~g}$; Mineral content: $350.00 \mathrm{~g}$; Niacin: 7,200.00 mg; Nicarbazin: $24.00 \mathrm{~g}$; Calcium pantothenate: $2400.00 \mathrm{mg}$; Selenium: $60.00 \mathrm{mg}$; Vitamin A: 1,920,000.00 IU; Vitamin B1: $300.00 \mathrm{mg}$; Vitamin B12: 3,600.00 mg; Vitamin B2: 1,200.00 mg; Vitamin B6: $450.00 \mathrm{mg}$; Vitamin D3: 360,000.00 IU; Vitamin E: 3,600.00 IU; Vitamin H: $18.00 \mathrm{mg}$; Vitamin $\mathrm{K}$ : $480.00 \mathrm{mg}$; Zinc: $22.00 \mathrm{~g} ;{ }^{2}$ Calculated according to Mongin (1981): Electrolyte balance $=(\mathrm{mg} / \mathrm{kg}$ of dietary Na$/ 22.990)+(\mathrm{mg} / \mathrm{kg}$ of dietary $\left.\mathrm{K}^{+} / 39.102\right)$ - $\left(\mathrm{mg} / \mathrm{kg}\right.$ of dietary $\left.\mathrm{Cl}^{-} / 35.453\right) ; \mathrm{ME}=$ metabolizable energy.

Based on FI, excreta production, DM (\%), nitrogen $(\mathrm{N})$ and $\mathrm{GE}(\mathrm{kcal} / \mathrm{kg})$ analysis of the diets and excreta, the apparent metabolizable energy (AME) and nitrogen-corrected apparent metabolizable energy $\left(\mathrm{AME}_{\mathrm{n}}\right)$ were determined using the equations proposed by Matterson et al. (1965).

$$
\begin{aligned}
& \text { DietaryAME }(\mathrm{kcal} / \mathrm{kg})=\underline{(\text { GEint }- \text { GEexc })} \\
& \mathrm{Dm}_{\text {int }} \\
& \text { Dietary } \mathrm{AME}_{\mathrm{n}}(\mathrm{kcal} / \mathrm{kg})=\frac{\text { GEint }-(\mathrm{GEexc} \pm 8.22 \times \mathrm{NB})}{\mathrm{DM}_{\mathrm{int}}} \times 100
\end{aligned}
$$

where $\mathrm{AME}=$ apparent metabolizable energy $(\mathrm{kcal} / \mathrm{kg}) ; \mathrm{AME}_{\mathrm{n}}=$ nitrogen-corrected apparent metabolizable energy $(\mathrm{kcal} / \mathrm{kg}) ;$ GEint $=$ gross energy intake $(\mathrm{kcal}) ;$ GEexc $=$ gross energy excreted (kcal); $\mathrm{NB}=$ nitrogen balance $((\mathrm{DM}$ intake $\mathrm{x}$ dietary $\mathrm{N})$ - (DM excreted $\mathrm{x} \mathrm{N}$ excreted $)$ ) and DMint $=$ dry matter intake $(\mathrm{kg})$.

The apparent metabolizable coefficients (AMC) of the nutrients (DMMC, CPMC and GEMC), were also determined according to the equation described by Sakomura and Rostagno (2007):

$\operatorname{AMC}(\%)=(\mathrm{g}$ of the ingested nutrient $-\mathrm{g}$ of the excreted nutrient $) \times 100$ $\mathrm{g}$ of the ingested nutrient

In the performance experiment, 200 male broilers from the Cobb $500^{\circledR}$ lineage were fed with commercial feed and raised until 7-days- old, according to the breed manual recommendations.

The broilers were bred in an experimental shed with a concrete floor covered with babassu straw, and located in cages of $1.0 \times 1.0 \times 0.5 \mathrm{~m}$, with gutter feeders and drinkers. The supply of feeders and the cleaning and refueling of drinkers were performed twice a day, to ensure free access to water and feed throughout the experimental period.

On the $8^{\text {th }}$ day, the broilers with an average weight of $184 \pm 19.86 \mathrm{~g}$ were combined and the treatments distributed in a CRD with four treatments $(0,2,4$ and $6 \%$ purified glycerin inclusion) and five replicates of ten broilers per experimental unit.

Until the $14^{\text {th }}$ day old, the broilers were heated artificially, using incandescent lamps $(60 \mathrm{~W})$ located inside the cages. Environmental conditions inside the facility during the experimental period were monitored and temperature and relative humidity were recorded daily every 5 minutes using HOBO data loggers (OnSet ${ }^{\circledR}$ Computer Corp., software version 3.4.1), placed halfway up the cages.

The experimental diets were formulated by considering the purified glycerin chemical composition (Table 2) and the nutritional requirements for broilers, according to the recommendations of Rostagno et al. (2011) (Table $3)$. 
Table 2. Purified glycerin composition used to formulate the experimental diets

\begin{tabular}{ll}
\hline Nutrients and energy & Purified glycerin \\
\hline Crude protein $(\%)^{2}$ & 0.23 \\
Metabolizable energy $(\mathrm{kcal} / \mathrm{kg})^{2}$ & 3510 \\
Dry matter $(\%)^{1}$ & 89.98 \\
${\text { Ether extract }(\%)^{1}}^{1}$ & 1.19 \\
Mineral content $(\%)^{1}$ & 7.86 \\
Methanol $(\mathrm{g} / \mathrm{kg})^{1}$ & $<0.1$ \\
$\mathrm{Glycerol}(\%)^{1}$ & 80.4 \\
$\mathrm{NaCl}(\%)^{1}$ & 7.47 \\
$\mathrm{Na}(\%)^{1}$ & 2.96 \\
\hline
\end{tabular}

${ }^{1}$ Glycerin from the processing of soybeans sold in south Brazil; ${ }^{2}$ Rostagno et al. $(2011) ;{ }^{3}$ Approximate values according to the manufacturer.

Table 3. Composition of experimental diets containing increasing levels of purified glycerin for broilers from 8 to 21 days old

\begin{tabular}{|c|c|c|c|c|}
\hline \multirow[b]{2}{*}{ Ingredients } & \multicolumn{4}{|c|}{ Inclusion levels of purified glycerin (\%) } \\
\hline & 0 & 2 & 4 & 6 \\
\hline Corn meal & 61.498 & 59.251 & 57.004 & 54.738 \\
\hline Soybean meal (45\%) & 33.167 & 33.607 & 34.044 & 34.487 \\
\hline Purified glycerin & 0.000 & 2.000 & 4.000 & 6.000 \\
\hline Dicalcium phosphate & 1.783 & 1.789 & 1.793 & 1.798 \\
\hline Soybean oil & 1.346 & 1.309 & 1.273 & 1.243 \\
\hline Limestone & 0.826 & 0.820 & 0.816 & 0.810 \\
\hline Salt & 0.436 & 0.286 & 0.139 & 0.000 \\
\hline DL-Methionine & 0.248 & 0.250 & 0.253 & 0.255 \\
\hline L-Lysine $\mathrm{HCl}$ & 0.234 & 0.227 & 0.218 & 0.209 \\
\hline L-Threonine & 0.062 & 0.061 & 0.060 & 0.060 \\
\hline Mineral and vitamin supplement ${ }^{1}$ & 0.400 & 0.400 & 0.400 & 0.400 \\
\hline Total & 100.00 & 100.00 & 100.00 & 100.00 \\
\hline \multicolumn{5}{|l|}{ Calculated nutritional composition } \\
\hline $\mathrm{ME}(\mathrm{kcal} / \mathrm{kg})$ & 3000 & 3000 & 3000 & 3000 \\
\hline Crude protein $(\%)$ & 20.79 & 20.79 & 20.79 & 20.79 \\
\hline Calcium $(\%)$ & 0.884 & 0.884 & 0.884 & 0.884 \\
\hline Available phosphorus (\%) & 0.442 & 0.442 & 0.442 & 0.442 \\
\hline Digestible lysine $(\%)$ & 1.146 & 1.146 & 1.146 & 1.146 \\
\hline Methionine + digestible cystine (\%) & 0.814 & 0.814 & 0.814 & 0.814 \\
\hline Digestible methionine $(\%)$ & 0.536 & 0.538 & 0.541 & 0.541 \\
\hline Digestible threonine $(\%)$ & 0.745 & 0.750 & 0.745 & 0.745 \\
\hline Ether extract $(\%)$ & 3.918 & 3.834 & 3.799 & 3.672 \\
\hline Sodium $(\%)$ & 0.214 & 0.214 & 0.214 & 0.214 \\
\hline Potassium (\%) & 0.294 & 0.204 & 0.115 & 0.031 \\
\hline Chlorine $(\%)$ & 0.795 & 0.797 & 0.797 & 0.799 \\
\hline Electrolyte balance $(\mathrm{meq} / \mathrm{kg})^{2}$ & 213.5 & 239.4 & 264.5 & 288.7 \\
\hline
\end{tabular}

${ }^{1}$ Composition (ton ${ }^{-1}$ ): Folic Acid: $150.00 \mathrm{mg}$; Cobalt: $178.00 \mathrm{mg}$; Copper: $2675.00 \mathrm{mg}$; Choline: $120.00 \mathrm{~g}$; Colistin: 2,000.00 mg; Iron: 11.00 g; Iodine: $535.00 \mathrm{mg}$; Manganese: $31.00 \mathrm{~g}$; Mineral content: $350.00 \mathrm{~g}$; Niacin: 7,200.00 mg; Nicarbazin: $24.00 \mathrm{~g}$; Calcium pantothenate: $2400.00 \mathrm{mg}$; Selenium: $60.00 \mathrm{mg}$; Vitamin A: 1,920,000.00 IU; Vitamin B1: $300.00 \mathrm{mg}$; Vitamin B12: 3,600.00 mg; Vitamin B2: 1,200.00 mg; Vitamin B6: $450.00 \mathrm{mg}$; Vitamin D3: 360,000.00 IU; Vitamin E: 3,600.00 IU; Vitamin H: $18.00 \mathrm{mg}$; Vitamin K: $480.00 \mathrm{mg}$; Zinc: $22.00 \mathrm{~g}$; ${ }^{2}$ Calculated according to Mongin (1981): Electrolyte balance $=(\mathrm{mg} / \mathrm{kg}$ of dietary Na$/ 22.990)+(\mathrm{mg} / \mathrm{kg}$ of dietary $\left.\mathrm{K}^{+} / 39.102\right)$ - $\left(\mathrm{mg} / \mathrm{kg}\right.$ of dietary $\left.\mathrm{Cl}^{-} / 35.453\right)$; $\mathrm{ME}=$ metabolizable energy.

The data of variables were submitted to Cramér-von Mises normality test and Levene's homoscedasticity test. The variables were subjected to analysis of variance to ensure they met these assumptions. The variables were subjected to regression analysis using polynomial models of first 
or second order, considering the inclusion level of purified glycerin as an independent variable. The adjustment of the equation was checked by considering the F-test significance for the models, the $t$-test significance for the parameters $(\beta 0, \beta 1$ and $\beta 2$ ) of the models and the coefficient of determination $\left(\mathrm{R}^{2}=\mathrm{SS}\right.$ regression $/ \mathrm{SS}$ total $)$, at a significance level of $p \leq 0.05$. Statistical analyses were performed using SISVAR statistical program.

The feeding costs were determined considering that the treatments that were used in the production systems required the same inputs, differing only as the provided diets. The cost difference between treatments was quantified using only the costs of the poultry feed (PEREIRA et al., 2003).

The economic efficiency of the experimental diets was compared by determining the feed cost per $\mathrm{kg}$ of broiler produced as follows: $\mathrm{FC}_{\mathrm{i}}=\left(\mathrm{FI}_{\mathrm{i}} \times \mathrm{RC}_{\mathrm{i}}\right) / \mathrm{WG}_{\mathrm{i}}$; with $\mathrm{i}=1,2,3,4$.

where $\mathrm{FC}_{\mathrm{i}}=$ feeding cost per $\mathrm{kg}$ of broiler produced with the use of the $i^{\text {th }}$ purified glycerin inclusion level $(\mathrm{R} \$ / \mathrm{kg}), \mathrm{FI}_{\mathrm{i}}=$ feed intake in the $\mathrm{i}^{\text {th }}$ purified glycerin inclusion level $(\mathrm{kg}), \mathrm{RC}_{\mathrm{i}}=$ ration cost containing the $\mathrm{i}^{\text {th }}$ purified glycerin inclusion level $(\mathrm{R} \$ / \mathrm{kg})$ and $\mathrm{WG}_{\mathrm{i}}=$ weight gain of broilers receiving the $\mathrm{i}^{\text {th }}$ purified glycerin inclusion level $(\mathrm{kg})$.

The gross margin relative to the feeding cost per kg of broiler for each purified glycerin inclusion level in the diet was calculated by the following: $\mathrm{GM}_{\mathrm{i}}=\mathrm{BSP}-\mathrm{FC}_{\mathrm{i}}$; where $\mathrm{GM}_{\mathrm{i}}=$ gross margin relative to the feeding cost per kg of broiler obtained from the use of the $\mathrm{i}^{\text {th }}$ purified glycerin inclusion level $(\mathrm{R} \$) ; \mathrm{BSP}=$ live broiler selling price $(\mathrm{R} \$ / \mathrm{kg})$ and $\mathrm{FC}_{\mathrm{i}}=$ cost per $\mathrm{kg}$ of broiler produced with the use of the $\mathrm{i}^{\text {th }}$ purified glycerin inclusion level $(\mathrm{R} \$ / \mathrm{kg})$.

\section{RESULTS AND DISCUSSION}

Average air, maximum and minimum temperatures inside the facility during the experimental period were $25.6,32.8$ and $20.8^{\circ} \mathrm{C}$, respectively, and the relative humidity was $85 \%$. These data showed that broilers were within the thermal neutral zone throughout the trial period because daily values of air temperature were within the recommended range for the different life stages, both for the phase from 8-14 and 14-21 days old (CORDEIRO et al., 2010; OLIVEIRA et al., 2006).

The high values of relative humidity can be justified by heavy rainfalls during the trial period. Possibly, these values did not affect broiler performance because the air temperature values were within the thermoneutral range.

The AME content of purified glycerin was $3790 \mathrm{kcal} \mathrm{kg}^{-1}$ (Table 4). This value was similar to that found by Henz et al. (2014a), who determined the AME content for broilers from 20-30 days old (3815 kcal kg-1) but lower than the value found by Oliveira et al. (2013) of pure glycerin, which was $4015 \mathrm{kcal} \mathrm{kg}^{-1}$.

Table 2. Mean values of apparent metabolizable energy (AME), nitrogen-corrected apparent metabolizable energy $\left(\mathrm{AME}_{\mathrm{n}}\right)$, and metabolizability coefficients of dry matter (DMMC), crude protein (CPMC), and gross energy (GEMC) of purified glycerin ${ }^{1}$

\begin{tabular}{|c|c|}
\hline Variables & Energy value \\
\hline $\operatorname{AME}(\mathrm{kcal} / \mathrm{kg})^{2}$ & 3790 \\
\hline $\operatorname{AME}_{\mathrm{n}}(\mathrm{kcal} / \mathrm{kg})^{2}$ & 3560 \\
\hline \multicolumn{2}{|c|}{ Metabolizability coefficients } \\
\hline Dry matter $(\%)^{2}$ & 83.72 \\
\hline Crude protein $(\%)^{2}$ & 71.52 \\
\hline Gross energy $(\%)^{2}$ & 86.27 \\
\hline
\end{tabular}

${ }^{1}$ Expressed in organic matter; ${ }^{2}$ Analyses were carried out at the Animal Nutrition Laboratory of the School of Veterinary Medicine and Animal Science from the Federal University of Tocantins.

The $\mathrm{AME}_{\mathrm{n}}$ value of $3560 \mathrm{kcal} \mathrm{kg}^{-1}$ obtained for the purified glycerin (Table 4), was similar to that found by Dozier et al. (2008), who conducted three experiments with broilers of various ages and obtained an $\mathrm{AME}_{\mathrm{n}}$ mean value of $3434 \mathrm{kcal} \mathrm{kg}^{-1}$. It was also within the range $\left(\mathrm{AME}_{\mathrm{n}} 3254-4134 \mathrm{kcal}\right.$ $\mathrm{kg}^{-1}$ ) found by Dozier et al. (2011), when evaluating different samples of glycerin. These results support those already reported in the literature, in which glycerin is considered an efficient energy source for broiler nutrition (JUNG; BATAL, 2011a; LAMMERS et al., 2008; McLEA et al., 2011; TOPAL; OZDOGAN, 2013). It can be stated that glycerol, because it has a high metabolizable energy value and is easily digestible, can be used to food broiler chickens as an energy source without 
influencing the performance of the birds during the different phases of production.

However, Gianfelici et al. (2011) and Henz et al. (2014a) emphasized that $\mathrm{AME}_{\mathrm{n}}$ values are difficult to determine, as they may vary according to the product characteristics, the glycerin inclusion level in the diet and the age of broilers. Therefore, it is important to carry out the bromatological analyzes of the food before are the birds fed, due to the lack of standardization in the glycerin industrialization process.

The DMMC, CPMC and GEMC values of purified glycerine (Table 4), were in agreement with those found by Abd-Elsamee et al. (2010), who tested $0,2,4,6$ and $8 \%$ of crude glycerin in the feed of broilers and found no effects on metabolizable coefficients for the nutrients.

Purified glycerin inclusion levels in the diets did not affect ( $p>0.05)$ FI, weight gain (WG), feed conversion (FCR) and broiler weight at 21 days (W21d) (Table 5). These results may be attributed to formulating the experimental diets to be isoenergetic and isoproteic, meeting the nutritional requirements of the broilers in all the treatments, regardless of the purified glycerin inclusion level.

Table 3. Average feed intake (FI), weight gain (WG), feed conversion (FCR) and weight values at 21 days (W21d) of broilers from 8 to 21 days, according to the inclusion level of purified glycerin

\begin{tabular}{|c|c|c|c|c|c|c|c|c|c|}
\hline \multirow{2}{*}{ Variables } & \multicolumn{4}{|c|}{ Purified glycerin inclusion level (\%) } & \multirow{2}{*}{ Mean } & \multicolumn{3}{|l|}{$\mathrm{P}$} & \multirow{2}{*}{$\begin{array}{l}\mathrm{CV}^{1} \\
(\%)\end{array}$} \\
\hline & 0 & 2 & 4 & 6 & & LE & $\mathrm{QE}$ & LD & \\
\hline $\mathrm{FI}^{2}(\mathrm{~g})$ & 1151.0 & 1160.2 & 1170.8 & 1157.0 & 1159.7 & 0.441 & 0.175 & 0.487 & 1.56 \\
\hline $\mathrm{WG}^{3}(\mathrm{~g})$ & 762.5 & 769.4 & 763.5 & 762.9 & 764.8 & 0.856 & 0.539 & 0.505 & 1.76 \\
\hline $\mathrm{FCR}^{4}(\mathrm{~g} / \mathrm{g})$ & 1.51 & 1.51 & 1.53 & 1.52 & 1.52 & 0.433 & 0.684 & 0.257 & 2.13 \\
\hline $\mathrm{W} 21 \mathrm{~d}^{5}(\mathrm{~g})$ & 943.9 & 943.1 & 912.6 & 924.1 & 930.9 & 0.223 & 0.707 & 0.328 & 3.80 \\
\hline
\end{tabular}

${ }^{1}$ Coefficient of variation $(\%) ;{ }^{2,3,4,5} \hat{\mathrm{Y}}=\mathrm{NS}$; LE = linear effect; $\mathrm{QE}=$ quadratic effect; $\mathrm{LD}=$ linearity deviation; $\mathrm{P}=$ probability of type $\mathrm{I}$ error using the F-test.

The lack of effect on broilers performance variables may be related to the fact that the diets were formulated to be isoenergetic and isoproteic, which met the nutritional requirements of the birds in all treatments. Similar results were found by Henz et al. (2014b) who assessed the inclusion of 0 , $3,6,9,12$ and $15 \%$ of crude glycerine in broiler diets from 1 to 21 days old and found that glycerin inclusion at up to $6.06 \%$ did not have any effect on performance, protein and fat depositions in the carcass and litter moisture.

Likewise, Topal and Ozdogan (2013) evaluated glycerin levels $(0.4$ and $8.0 \%)$ in broiler diets from 1 to 42 days old and observed its efficiency as an energy source, particularly in broilers from 1 to 21 days old. The authors explained that the improved performance of broilers in the initial phase is associated with the greater bioavailability of glycerin compared to other feeds, except oils and glucose.

Evaluating three different glycerin sources (crude, mixed and semi-purified) and four inclusion levels $(1.75,3.50,5.25$ and $7.0 \%)$, Bernardino et al. (2014) observed that broilers fed diets containing crude and semi-purified glycerin linearly increased serum glycerol concentrations and concluded that the studied glycerins can be included in the diet at up to $7 \%$ without impairing the performance of broiler chickens from 8 to 21 days old. Mandalawi et al. (2014) tested 2.5, 5.0, 7.5 and 10\% glycerin in the feed of broilers from 1 to 21 days and concluded that glycerin can be used to replace the dietary energy sources at up to $10 \%$ without any negative effect on the broiler performance.

However, it should be emphasized that the use of higher levels of glycerin in the present study (i.e. $>6 \%$ ) was limited by its high sodium chloride content $(7.47 \%)$, corresponding to $2.96 \%$ sodium (Na) (Table 2). When considering the composition of nutrients in the diets, levels above $6 \%$ glycerine inclusion exceed the nutritional requirements for $\mathrm{Na}$, according to the recommendations of Rostagno et al. (2011).

Based on a feeding cost analysis, the highest gross margin was obtained for broilers fed with the inclusion of $6 \%$ purified glycerol due to having the lowest feed cost (Table 6). The increase in the purified glycerin inclusion levels decreased the feed cost due to the decreased corn and soybean oil contents in the diet (Table 2). Thus, it is economically feasible to include purified glycerin in broiler diets from 8 to 21 days old. 
Table 4. Weight gain ( $\mathrm{g})$, feeding cost $(\mathrm{R} \$ / \mathrm{kg})$, feeding cost per $\mathrm{kg}$ of weight gain $(\mathrm{R} \$ / \mathrm{kg})$ and gross margin $(\mathrm{R} \$ / \mathrm{kg})$ of broilers from 8 to 21 days.

\begin{tabular}{lllll}
\hline \multirow{2}{*}{ Variables } & \multicolumn{4}{c}{ Purified glycerin inclusion level $(\%)$} \\
\cline { 2 - 5 } & 0 & 2 & 4 & 6 \\
\hline Weight gain $(\mathrm{g})$ & 762.51 & 749.80 & 757.40 & 742.86 \\
Feeding cost $^{1}(\mathrm{R} \$ / \mathrm{kg})$ & 1.258 & 1.255 & 1.252 & 1.249 \\
Feeding cost per kg of weight gain $(\mathrm{R} \$ / \mathrm{kg})$ & 1.897 & 1.892 & 1.888 & 1.884 \\
Gross margin $^{2}(\mathrm{R} \$ / \mathrm{kg})$ & 0.903 & 0.908 & 0.912 & 0.916 \\
\hline
\end{tabular}

${ }^{1}$ Consider the following prices: Corn $=\mathrm{R} \$ 0.70 / \mathrm{kg}$; Soybean meal $=\mathrm{R} \$ 1.76 / \mathrm{kg}$; Purified glycerin $=\mathrm{R} \$ 0.38 / \mathrm{kg} ;$ Dicalcium phosphate $=$ $\mathrm{R} \$ 2.40 / \mathrm{kg}$; Soybean oil = R\$ 2.67/kg; Limestone $=\mathrm{R} \$ 0.44 / \mathrm{kg} ;$ Salt $=0.75 / \mathrm{kg} ;$ DL-methionine $=\mathrm{R} \$ 26.35 / \mathrm{kg} ; \mathrm{L}-\mathrm{lysine} \mathrm{HCl}=\mathrm{R} \$$ $13.27 / \mathrm{kg} ; \mathrm{L}$-threonine $=\mathrm{R} \$ 10.63 / \mathrm{kg} ;$ Mineral and vitamin supplement $=\mathrm{R} \$ 13.80 / \mathrm{kg} ;{ }^{2}$ Considering the price of live broilers paid on July $3^{\text {rd }}, 2014=\mathrm{R} \$ 2.80 / \mathrm{kg}$ (ASA North Company).

Overall, the results of this study showed that the purified glycerin inclusion levels evaluated in the diets did not affect the performance of broilers from 8 to 21 days of age. Therefore, its use is technically and economically feasible because the energy and protein levels in the diets were balanced to meet the broiler nutritional requirements.

\section{CONCLUSIONS}

The AME and $\mathrm{AME}_{\mathrm{n}}$ values of purified glycerin obtained in this study were 3790 and 3560 $\mathrm{kcal} / \mathrm{kg}$, respectively.

The inclusion of up to $6 \%$ purified glycerin in broiler diets from 8 to 21 days old proved to be technically and economically feasible because the broiler nutritional requirements are met.

\section{ACKNOWLEDGEMENTS}

Coordination for the Improvement Higher of Education Personnel (CAPES), for granting the scholarship, the Federal University of Tocantins (UFT), for the support and availability of facilities and the ASA-Norte Foods and GRANFORTE for supplying the raw material to carry out the experiments.

"The development of this research benefited from the UFT Institutional Productivity Research Program (PROPESQ / UFT)".

RESUMO: Objetivou-se neste trabalho avaliar a metabolizabilidade, o desempenho zootécnico e a viabilidade econômica da inclusão de glicerina purificada, em dietas balanceadas para frangos de corte dos 8 aos 21 dias de idade. Foram realizados dois experimentos, sendo que, no primeiro experimento, foram utilizados 100 pintos de 14 dias de idade, distribuídos em delineamento inteiramente casualizado (DIC), com dois tratamentos, cinco repetições de 10 aves. Os tratamentos consistiram de uma dieta referência e uma dieta teste, na qual a glicerina purificada substituiu $10 \%$ da dieta referência. No segundo experimento, foram utilizados 200 pintos de 8 dias de idade, distribuídos em delineamento experimental inteiramente casualizado (DIC), com quatro tratamentos $(0,2,4$ e $6 \%$ de inclusão de glicerina purificada) e cinco repetições de 10 aves. Foram determinados o ganho de peso, consumo de ração, conversão alimentar, peso final, energia metabolizável aparente (EMA), energia metabolizável aparente corrigida pelo balanço de nitrogênio (EMA ${ }_{n}$ ), os coeficientes de metabolizabilidade da matéria seca (CMMS), proteína bruta (CMPB), energia bruta (CMEB) e o custo da alimentação por kg de frango produzido. A EMA, EMA $\mathrm{n}_{\mathrm{n}}$ os CMMS, CMPB, CMEB da glicerina purificada obtida foram de $3790,3560 \mathrm{Kcal} / \mathrm{kg}$ e 83,72, 71,52, 86,27\%, respectivamente. Observou-se que a inclusão de glicerina purificada não afetou $(p>0,05)$ o desempenho (ganho de peso, consumo de ração, conversão alimentar e peso final). $\mathrm{O}$ menor custo com a alimentação e a maior margem bruta foi obtido com os frangos alimentados com $6 \%$ de inclusão de glicerina purificada. A inclusão de $6 \%$ de glicerina purificada em dietas balanceadas para frangos de corte dos 8 aos 21 dias de idade, mostrou-se técnica e economicamente viável.

PALAVRAS CHAVE: Alimento energético. Biodiesel. Custo da alimentação. Desempenho produtivo. Energia metabolizável. 


\section{REFERENCES}

ABD-ELSAMEE, M. O.; ABDO, Z. M. A.; EL-MANYLAWI, M. A. F.; SALIM, I. H. Use of crude glycerin in broiler diets. Egyptian Poultry Science, Alexandria, v. 30, n. 1, p. 281-295, 2010.

https://www.cabdirect.org/cabdirect/abstract/20113051703

BERNARDINO, V. M. P.; RODRIGUES, P. B.; OLIVEIRA, D. H. D.; FREITAS, R. T. F. D.; Naves, L. D. P.; NARDELLI, N. B. D. S.; TEIXEIRA, L. V.; PREZOTTO, C. F. Fontes e níveis de glicerina para frangos de corte no período de 8 a 21 dias de idade. Revista Brasileira de Saúde e Produção Animal, v. 15, n. 3, p. 649658, 2014. http://dx.doi.org/10.1590/S1519-99402014000300012

CERRATE, S.; YAN, F.; WANG, Z.; COTO, C.; SACAKLI, P.; WALDROUP, P. W. Evaluation of glycerine from biodiesel production as a feed ingredient for broilers. International Journal of Poultry Science,

Faisalabad, v. 5, n. 11, p. 1001-1007, 2006. http://dx.doi.org/10.3923/ijps.2006.1001.1007

CORDEIRO, M. B.; TINÔCO, I. F. F.; SILVA, J. N.; VIGODERIS, R. B.; PINTO, F. A. C.; CECON, P. R. Conforto térmico e desempenho de pintos de corte submetidos a diferentes sistemas de aquecimento no período de inverno. Revista Brasileira de Zootecnia, Viçosa, v. 39, n. 1, p. 217-224, 2010.

http://dx.doi.org/10.1590/S1516-35982010000100029

DOZIER, W. A.; KERR, B. J.; BRANTON, S. L. Apparent metabolizable energy of crude glycerin originating from different sources in broiler chickens. Poultry Science, Champaign, v. 90, n. 11, p. 2528-2534, 2011. http://dx.doi.org/ 10.3382/ps.2011-01510

DOZIER, W. A.; KERR, B. J.; CORZO, A.; KIDD, M. T.; WEBER, T. E.; BREGENDOAHL, K. Apparent metabolizable energy of glycerin for broiler chickens. Poultry Science, Champaign, v. 87, n. 2, p. 317-322, 2008. http://dx.doi.org/ 10.3382/ps.2007-00309

GIANFELICI, M. F.; RIBEIRO, A. M. L.; PENZ JÚNIOR, A. M.; KESSLER, A. M.; VIEIRA, M. M.; MACHINSKY, T. Determination of apparent metabolizable energy of crude glycerin in broilers chickens. Brazilian Journal of Poultry Science, Campinas, v. 13, n. 4, p. 255-258, 2011. http://dx.doi.org/10.1590/S1516-635X2011000400006

GUERRA, R. L. H.; MURAKAMI, A. E.; GARCIA, A. F. Q. M.; URGNANI, F. J.; MOREIRA, I.; PICOLI, K. P. Glicerina bruta mista na alimentação de frangos de corte (1 a 42 dias). Revista Brasileira de Saúde e Produção Animal, Salvador, v. 12, n. 4, p. 1038-1050, 2011.

http://revistas.ufba.br/index.php/rbspa/article/viewArticle/2295

HENZ, J. R.; NUNES, R. V.; EYNG, C.; SILVA, Y. L.; SCHONE, R. A.; OLIVEIRA, T. M. M.; BERWANGER, E.; SANGALI, C.P. Energia metabolizável da glicerina bruta para frangos de corte de diferentes idades. Semina: Ciências Agrárias, Londrina, v. 35, n. 6, p. 3393-3400, 2014a.

http://dx.doi.org/10.5433/1679-0359

HENZ, J. R.; NUNES, R. V.; EYNG, C.; POZZA, P. C.; FRANK, R.; SCHONE, R. A.; OLIVEIRA, T. M. M. Effect of dietary glycerin supplementation in the starter diet on broiler performance. Czech Journal of Animal Science, Kamýcká, v. 59, n. 12, p. 557-563, 2014b. http://dx.doi.org/10.17221/7795-CJAS

JUNG, B.; BATAL, A. B. Nutritional and feeding value of crude glycerin for poultry. 1. Nutritional value of crude glycerin. Journal of Applied Poultry Research, Champaign, v. 20, n. 2, p. 162-167, 2011 a. https://doi.org/10.3382/japr.2010-00235

JUNG, B.; BATAL, A. B. Nutritional and feeding value of crude glycerin for poultry. 2. Evaluation of feeding crude glycerin to broilers. Journal of Applied Poultry Research, Champaign, v. 20, n. 2, p. 514-527, 2011 b. https://doi.org/10.3382/japr.2011-00338 
LAMMERS, P. J.; KERR, B. J.; HONEYMAN, M. S.; STALDER, K.; DOZIER, W. A.; WEBER, T. E.; KIDD, M. T.; BREGENDAHL, K. Nitrogen-corrected apparent metabolizable energy value of crude glycerol for laying hens. Poultry Science, Champaign, v. 87, n. 1, p. 104-107, 2008. https://doi.org/10.3382/ps.200700255

LIMA, E. M. C.; RODRIGUES, P. B.; ALVARENGA, R. R.; BERNARDINO, V. M. P.; MAKIYAMA, L.; LIMA, R. R.; CANTARELLI, V. S.; ZANGERONIMO, M. G. The energy value of biodiesel glycerine products fed to broilers at different ages. Journal of Animal Physiology and Animal Nutrition, Berlin, v. 97, n. 5, p. 896-903, 2013. http://dx.doi.org/10.1111/j.1439-0396.2012.01335

MANDALAWI, H. A.; KIMIAEITALAB, M. V.; OBREGON, V.; MENOYO, D.; MATEOS, G. G. Influence of source and level of glycerin in the diet on growth performance, liver characteristics, and nutrient digestibility in broilers from hatching to 21 days of age. Poultry Science, Champaign, v. 93, n. 11, p. 2855-2863, 2014. https://doi.org/10.3382/ps.2014-04156

MATTERSON, L. D.; POTTER, L. M.; STUTZ, M. W. The metabolizable energy of feed ingredients for chickens. Storrs: The University of Connecticut, Agricultural Experiment Station, 11 p, 1965.

https://www.cabdirect.org/cabdirect/abstract/19671403742

McLEA, L.; BALL, M. E. E.; KILPATRICK, D.; ELLIOTT, C. The effect of glycerol inclusion on broiler performance and nutrient digestibility. British Poultry Science, London, v. 52, n. 3, p. 368-375, 2011. https://doi.org/10.1080/00071668.2011.584520

MONGIN, P. Recent advances in dietary cation-anion balance: applications in poultry. Proceedings of the Nutrition Society, Cambridge, v. 40, n. 3, p. 285-294, 1981. https://www.ncbi.nlm.nih.gov/pubmed/7301833 https://doi.org/10.1079/PNS19810045

OLIVEIRA, D. D. de.; PINHEIRO, J. W.; OBA, A.; FONSECA, N. A. N. Desempenho de frangos de corte alimentados com glicerina pura. Semina: Ciências Agrárias, Londrina, v. 34, n. 6, supplement 2, p. 40834092, 2013. http://dx.doi.org/10.5433/1679-0359

OLIVEIRA, R. F. M.; DONZELE, J. L.; ABREU, M. L. T.; FERREIRA, R. A.; VAZ, R. G. M. V.; CELLA, P. S. Efeitos da temperatura e da umidade relativa sobre o desempenho e o rendimento de cortes nobres de frangos de corte de 1 a 49 dias de idade. Revista Brasileira de Zootecnia, Viçosa, v. 35, n. 3, p. 797-803, 2006. http://dx.doi.org/10.1590/S1516-35982006000300023

PEREIRA, J. C.; SILVA, P. R. C.; CECON, P. R.; RESENDE FILHO, M. A.; OLIVEIRA, R. L. Cama de frango e suplemento à base de microbiota ruminal em dietas de novilhas leiteiras: desempenho produtivo e avaliação econômica. Revista Brasileira de Zootecnia, Viçosa, v. 32, n. 3, p. 653-662, 2003. http://dx.doi.org//10.1590/S1516-35982003000300017

ROMANO, G.G.; MENTEN, J. F. M.; FREITAS, L. W.; LIMA, M. B.; PEREIRA, R.; ZAVARIZE, K. C.; DIAS, C. T. S. Effects of glycerol on the metabolism of broilers fed increasing glycerine levels. Brazilian Journal of Poultry Science, Campinas, v. 16, n. 1, p. 97-106, 2014. http://dx.doi.org/ 10.1590/S1516$635 X 2014000100014$

ROSTAGNO, H. S.; ALBINO, L. F. T.; DONZELE, J. L.; GOMES, P. C.; OLIVEIRA, R. F.; LOPES, D. C.; FERREIRA, A. S.; BARRETO, S. L. T. Tabelas brasileiras para aves e suínos composição de alimentos e exigências nutricionais. 3. ed. Viçosa: UFV, Imprensa Universitária, 252 p, 2011.

SAKOMURA, N. K.; ROSTAGNO, H. S. Métodos de pesquisa em pesquisa em nutrição de monogástricos. Jaboticabal: UNESP, 283 p, 2007.

SILVA, D. J.; QUEIROZ, A. C. Análise de alimentos, métodos químicos e biológicos. 3. ed. Viçosa: UFV. 165 p, 2002. 
TOPAL, E.; OZDOGAN, M. Effects of glycerol on the growth performance, internal organ weights, and drumstick muscle of broilers. Journal of Applied Poultry Research, Champaign, v. 22, n. 1, p. 146-151, 2013. http://dx.doi.org/ 10.3382/japr.2012-00589 